\title{
「密航」と海の想像力
}

『火山島』における「密航」を中心として

Sangwook NAM(南相沋 : Associate Professor of Department of Japanese Language \& Literature and Director of Institute for Japanese Cultural Studies in Incheon National University)

四 indimina@inu.ac.kr

(韓国) 仁川大学校日語日文学科副教授及び同大学日本文化研究所長。日本戦後文学、比 較文学比較文化論、表象文化論。『三島由紀夫における「アメリカ」(東京：彩流社, 201 4)、「戦後日本文学における「朝鮮戦争」一朝鮮戦争と戦後日本のナショナル·アイデンティ ティ」(ソウル：Comparative Korean Studies, 2015)、「三島由紀夫における「京都」と「戦後 一 『金閣寺』を中心として一」(京都：『立命館言語文化研究』28巻3号, 2017)、「戦後日本文学 における「暴力」表象一三島由紀夫と大江健三郎における「暴力」表象を中心として一」(大 田：『日本言語文化』42巻. 2018)、「現代日本の「反知性主義」言説分析」(ソウル：『日本学 報』. 2019)など。

\section{The Meaning of the Stowaway in Kim Sok-Bum's Kazando}

This paper considers the meaning of the stowaway in Kim Sok-bum's Kazando, focusing on law being changed in post-war East Asia.

'Stowing away' in Kazando acts as a narrative device that most clearly highlights the role of various parties involved in the formulation of laws in post-war South Korea. The US military, which occupied Japan and South Korea after the war with strong military power, restricted the free movement of civilians between Korea and Japan to establish a stable Cold War regime. In addition, after the 4.3 in 1948, the free movement between the disputed regions of Jeju and the Korean Peninsula was restricted. With this situation as the background, this text shows not only the differences in the methods of occupation for South Korea and Japan, economic disparities and gender differences within South Korea are the motives behind stowaways through the representation of 'Stowing away'.

Although stowing away is illegal, in Kazando it also embodies life in the extreme, which Kim shows is indispensable and highlights Violence of law in East Asia.

Keywords Kim Sok-Bum(金石範), Kazando(『火山島』), $\cdot 3$ (四・三事件), StowAway(密航), Nomos(ノモス) 


\section{1 はじめに一「密航」という思考の可能性}

「海」の思考とはいかなるものなのか。大地はつねに境界を画定しょうとする法とか かわっていると見たカール・シュミットのことばを手がかりとして、「海」の思考を想 定することはどうだろうが。つまり「陸」の思考が「陸」への拘束力を持つ何らかの「法」 の生成及び維持に関わるならば、海の思考はそうした「陸」の「法」を越境しようとする何 らかの力とかかわるはずであろう。むろん、シュミットは、無主公山であった海が、 やがて「陸」の思考としての法一とりわけ、ヨーロッパ公法一によって次々と侵食されて いることを強く懸念してはいた。とはいえ、だからこそ、陸の法に拘束されない場を 設ける可能性として「海」の思考を想定することが求められる。

ここに「密航」に注目する価值がある。正規の出入国手続きを踏まず国境を渡る行為と いう意味をもつ密航は、誰もがみとめる通り、「陸」の「法」を侵犯する行為である。それ 故に密航者は、国によって摘発され、強制的に受容所に送られ、強制帰還させたりす る。このことは、趙慶嬉がすでに指摘した通り、密航が「国家が物理的暴力を作動させ るもっとも正当な根拠」であることを示す ${ }^{2}$ 。国民国家の法を犯すことによって、「陸」の 「法」の境界やありかたをもっとも明確に示す出来事が、まさに密航なのだ。

こうした問題意識のもとで在日朝鮮人の密航が近年注目されている。とりわけ、歴 史学分野では、戦前から戦後にかけて、政府機関の公式文書のみならず、在日朝鮮人作 家の文学テクスト、さらには密航当事者の証言までを取り上げて、密航のありようを明 らかにしようとしている3。政府の立場で記される法的記録だけでは、主権の働き方式 の「野蛮さ」のみならず、命をかけて「陸」の法を侵犯して超越しようとする行為者が抱え ていた切迫した存在危機を理解することはむずかしいからである。済州人の日本密航を 分析した趙慶嬉は、「戦後東アジアの冷戦的な位階秩序と構造的な不均等」という前提条 件の上で成り立つ「密航」は、済州島の人々にとって苦労話でも、英雄談でもない、依 然として歴史化されていない日常の領域に属する」出来事であったと言い4、金達寿の 『密航者』を始め、1970年代の在日文学を分析した高和正は、「朝鮮半島の分断という状況 のなか、如何にして政治的な主体になり得るのか、如何に朝鮮の現実に参加できるのか という問いかけ」に対する応答として「密航ないし帰国」があったという5。このこと は、時間や空間や人によって「密航」が異なる意味作用を引き起こすことを示してくれ る。要するに、研究が深まるにつれて、「密航」に対する認識も一枚岩ではなくなってい

\footnotetext{
1 カール・シュミット・新田邦夫(訳)『大地の)モスーヨーロッパ公法という国際法における』(慈学社出版, 2007), pp.14-25.

2 조경희「불완전한 영토, '밀항’하는 일상」(『사회와역사』106권, 2015), p.40.

3 권혁태•이정은·조경희(편)『주권의 야만』(한울엠플러스, 2017), pp.120-157/ 尹健次『在日の精神史』(岩波書 店, 2015), pp.192-201.
}

4 권혁태•이정은·조경희(편), 同書, p.156.

5 권혁태•이정은·조경희(편), 同書, p.326. 
るのである。

こうした成果の上で本稿では金石範の『火山島』を取り上げて「密航について考えて いきたい。

『火山島』は、韓国文学研究においては1948年済州で起きた4・3民衆蜂起を中心とした がゆえに、朝鮮半島における「4・3」の捉え直しの物語として意義をもつ 6 。このテクス 卜を通して、国家暴力によって日本への「亡命」を余儀なくされる民衆の名誉回復が行わ れたし、比較文学的には亡命文学(或いは亡命者文学)として読み解かれている7。ただ し、亡命文学として捉える場合も、このテクストにおける「密航はごく小さな問題でし か論じられない。というのも、「密航」は、民衆蜂起に挫折した多くの人がどのように日 本列島に移動したのかという問題を説明してくれるに止まっているからである。

ところが、注意深く読まなくとも、『火山島』における「密航は必ずしも亡命という 一点に帰結するわけではないということにすぐに気づく。のちほど確認することにな るわけだが、密航者がやがて亡命者になる前に、行われた密航のありようも大いに語ら れているのだ。このことは、『火山島』における「密航」も決して一枚岩的に解釈できない のみならず、それぞれの「密航をより注意深く読むことを読者に要請しているのでは なからうか。こうした問題設定の上で、本稿では『火山島』における「密航」に焦点を合わ せで山島』を読んでいきたい。

\section{2 東アジアにおける新しい境界線と制限される移動：}

\section{アメリカという法の出現}

『火山島』における「密航」を理解することは簡単ではない。というのも、この物語に おいて最初の「密航」が行われた1948年3月当時、日本と朝鮮半島は共に連合軍の占領と信 託統治のもとにあったので、この密航を処罰する明確な根拠としての国内法はまだ成立 していなかったからである。しかし、『火山島』における登場人物の意識のなかには、 自分が行う行為が密航だという確かな自覚がある。つまり彼らのなかにはそれが法を 違反する行為であることがつよく意識されているのだ。

では、このことをどう理解すれば良いのだろうか。このことは単に作家の勘違いに すぎないのだろうか。それとも、本土への渡航を厳しく管理していた植民地時代の認識 がまだ響いていたことを示しているのだろらか。これを検証するためにも、彼らが違 反したと意識している「法」が、テクストのなかでどのように描かれているのかを確か める必要がある。

6 고명철「해방공간의 혼돈과 섬의 혁명에 대한 김석범의 문학적 고투」(『영주어문』34. 2016), pp.183-217.

7 곽형덕「‘망명자문학’으로서의『화산도』(『한민족문화연구』57. 2017), pp.37-62. 권성우「망명, 혹은 밀항의 상상력」(『비평의 고독』, 소명출판, 2016), pp.339-362. 
『火山島』においてそれは、主人公李芳根が明仙館で手にした「解放一年誌」という本の なかで、連合軍司令官の「布告文」という形としてはっきり示されている8。「布告文」の 内容は「密航」と直接かかわっていないものの、未だ公式的な政府が成立していなかった 東アジアの占領空間において連合軍司令官の「布告文」が大地を支配する新しい法として 機能したことを想起させてくれる。

ただ『火山島』において示される東アジアを支配する「法」は一つだけではあるまい。 一つは太平洋アメリカ合衆国陸軍司令部によるものであり、もう一つはソ連軍司令部に よるものである。周知の通り、アメリカによって占領された日本と異なり、朝鮮半島で は北緯38度線を境に、北はソ連によって、南はアメリカ軍によって各々占領されたし、 それが原因となり、五年も経たないらちに異なる法を持つ、二つの政府が各々生まれ、 朝鮮半島に境界線が引かれたのである。『火山島』の舞台である、朝鮮半島のもっとも南 に位置する済州島は、アメリカ合衆国陸軍司令部の法の支配に置かれたのに、なぜ作者 は主人公李芳根を通してソ連軍司令部の「布告文」まで改めて示しているのだろうか。

それは「アメリカ占領軍の、とくに布告文第二号は二年半後の今日の現実が証明して いる事実そのまま」であること、すなわち、アメリカ占領軍の統治方式の酷さを示すた めである。ソ連軍司令部の布告文が、日本統治下で暮らしてきた朝鮮民族の苦痛に触れ た上で、「朝鮮人民自体が、かならず自己の幸福を創造するものにならねばならない」こ とを、解放の意味として与えているのに対し、アメリカのそれは、日本の敗戦がもつ意 味については何も触れず、ひらすら「占領軍の保全」と「占領地域の公衆治安・秩序の安全」 のみを強調する機械的な語りになっている。李芳根が見るには、いまの済州島の現実 は、この文書の違いからくるにほかならないのだ。異なる法と統治方式の存在は、済州 島の人々が武装逃走に走る大きな理由となるのだ。要するに、二つの布告文の提示は、 4 ・3が韓国政府と済州島とのあいだにだけ起こった出来事ではなく、東アジアにおいて 新しく境界を画定しようとする法と、それに対する人々とのあいだの出来事であること を示してくれるのである。

なるほど、新しい法の持ち主は、これまでとは異なる形で大地の境界を画定し、 人久の移動を制限する。日本と朝鮮半島の南を占領したアメリカは、これまで「日本国 民」として括られた人久を、「日本人」と「非日本人」に区別し、それぞれを「本国」へ帰還 させようとした9 9 。これを受けて、済州島に進駐したアメリカ軍も、「占領軍の保全」と「占 領地域の公衆治安・秩序の安全」のために、まずは済州島に駐屯していた日本帝国軍を武 装解除し、九州の佐世保へ移動させた。それと引き換えるかのように、徵兵・徵用など で日本に送られていた若者の多くが、済州島に帰還するようになる ${ }^{10}$ 。

こうした人の移動は一見原状回復のように見えるかもしれないが、工業製品の多く

8 金石範『火山島 I』(岩波書店, 2015), pp.23-32.

9 조경희「불완전한 영토, '밀항’하는 일상」(『사회와역사』106권, 2015), p.47.

10 文京洙『済州島四・三事件——島の国」の死亡再生の物語』(岩波書店, 2018), p.56. 
を日本に依存していた済州島に深刻な経済難を引き起こし、密輸や日本への密航が増え る原因となっていく。とりわけ、朝鮮半島の南部にコレラが流行るようになると、総司 令部は1946年5月本国へ帰還した「非日本人」の日本への再入国を禁止する布告を出した し11、それを受けて日本の政府や地方政府でも、密航者の取り締まりを行っていた。朝 鮮半島の南を占領した米軍政も、鄭榮垣が指摘している通り、「米の移出を心配し、懸賞 金を掛けて密航告発を奨励するほど」であった ${ }^{12}$ 。『山山島』における登場人物たちの意識 のなかに日本への渡航が「密航」であるという意識は、このような背景のもとに成り立つ のである。

既存の権力機構が崩壊し、新しい政府ができるまでにはある程度の秩序を維持した かったアメリカ軍にとって、新しい境界の確定とそれに伴う自由な移動の制限は不可避 な決定だったかもしれない。ただ、それによる副作用も少なくなかった。それは孤立 した島の物資不足の問題だけに止まらない。とりわけ、日本列島と朝鮮半島とのあいだ だけではなく、米ソによって朝鮮半島に引かれた境界線は、人々の政治的な信念と大地 の分割とのあいだにおけるズレを生じさせることとなる。

日本帝国の崩壊後、朝鮮半島の南を統治していたアメリカ軍政は、しばらくのあい だ地方の治安維持や民生問題の多くを人民委員会に依存していたが、信託統治反対運動 などで政治的な混乱に陥ると、直接共産党系の政治家を逮捕することで人民の自由な政 治的な行為を妨害する一方、旧日本帝国の政府機構や警察組織を早速復活させる。それ に、共産化されつつある北から南に入ってきた人々が組織した、西北青年団が引き起こ す暴力的な反共産化活動を黙認する。もともと一つの国のなかで対立しながらも共存で きる政治的な理念の違いが、無理な境界画定によって許されなくなるにつれて、これま でなかった新たな暴力が生まれるようになったのである。

『火山島』はこのような状況に置かれた済州島の人々が展開した武装闘争とその挫折の 物語であるが、戦前からすでに人や物の多くをその外部に依存するようになっていた済 州島だったからこそ、こうした境界画定による移動制限は一層大きかった。済州島の 人々にとって密航は、こうした強制的な境界画定に逆らうが故に、新しい法の作動に晒 されることとなるのだ。

\section{$34 \cdot 3$ 以前の日本密航一「密航者」の目から見る占領期日本}

ただし『火山島』における「密航」は、消極的な抵抗として描かれていないことが特徴 である。日常を営むために不可避に行われる密航の場面は敢えて回避され、物語の中心 的な出来事である武装闘争にかかわる密航に焦点が合わせられる。つまり、蜂起が起こ

11 조경희「불완전한 영토, '밀항'하는 일상」(사회와역사』106권, 2015), p.47.

12 정영환·임경화(역)『해방공간의 재일조선인사』(푸른역사, 2019), p.156. 
る約1ヶ月前に「地下」に潜んでいたパルチザンである康蒙九と南承之は、済州から密や かに船に乗り、山口県のある港に入り、そこから列車に乗り、神戸、大阪、東京を回っ て、武装蜂起のための資金を集め、再び済州に帰ってくるのだ。では、済州島の人久の 日常や亡命とは直接つながらないこの密航をどう理解すれば良いのか。

本格的な分析の前に、この「密航」は植民地時代から行われた「日常的な密航」の慣行が 未だに残っているが故に可能であったことを想起する必要がある。消費財を直接生産で きる施設を持たない小さな島にとって「陸」との交流は不可欠なことなので、戦争による 物資不足などで渡航が厳しく制限されればなおさら「密航」が活性されることは止むを得 ないことである。戦後済州島と日本列島とのあいだに行われた密航ルートを知り尽くし ている乗務員が乗船する船は、こうした歴史的な過程で成り立って当時の済州島の人久 の生の条件となっていたのである。

その上に、この「密航」の主体が、普通の商人ではなく、統治者に抵抗しようとする パルチザンであることに注意を払わなければならない。このことは、まず、カール・ シュミットが指摘しているような、パルチザンがもつ世界政治的な意味とかかわる。 シュミットは、ヨーロッパにおいてパルチザンがつねに「自己の宗教と祖国のために死 んだ郷土の土着の防御者」として表象される恐れがあるものの、実際は「正規の強力なも のの援助」に常に頼っていたことを強調している ${ }^{13}$ 。とりわけ、技術的闘争手段が常に 進化している現代においては、新しい兵器および機械を供給してくれる「同盟者の永続 的な援助」がどうしても必要となるというのだ。

しかし、済州島の場合は「国際」的な援助を得られなかった。確かに当時の南朝鮮米占 領軍司令官や中央新聞などでは、済州の 4 ・3をはじめ、南だけで行わ机る選挙に対する反 対闘争などを、「国際共産主義つまりソ連の策略によるもの」と主張してはいたし、長い 間いわゆる「韓国史」ではそのように記されていた。しかし『火山島』においては「もし済 州島蜂起がモスクワの指令による国際共産主義の陰謀なら、かつてのスペイン戦争と比 べるべくはないにしても、何らかの国際的な連帯や援助があってもよさそうなものだ」 が、「国際的な援助どころか、北朝鮮からもそれがあるわけではなかった」ということ は、「在日同胞からのカンパ組織一つを見ても自明のこと」だと語られている ${ }^{14}$ 。つまり 『火山島』において済州島の武装隊に対する外部の援助者は、敗戦後にも日本に残留して いる朝鮮民族だけだったとし、それは韓国政府による真相調査報告書からも確かめられ $ろ^{15}$ 。

ところで、当初は済州島の方からは、在日朝鮮人のみならず、日本共産党の援助も期 待されていたということが『火山島』において語られている。そこには、在日朝鮮人運動 が、歴史的な脈絡からして、日本共産党と少なからぬつながりをもっ」ていたという理

13 カール・シュミット『パルチザンの理論』(筑摩書房, 1995), p.147.

14 金石範『火山島III』(岩波書店, 2015), p.555.

15 제주 4 - 3 사건진상규명및희생자명예회복위원회『제주43사건 진상보고서』(선인, 2003), p.178. 
由がある ${ }^{16}$ 。尹健次は、「日本共産党の組織が壊滅的な状況であったなかで、GHQ/日本 政府に政治犯䣋放を粘り強く訴えつづけ、実現させたのは、金斗鎔ら朝鮮人活動家であ り、その後の日本共産党の再建活動で中心になったのも、在日朝鮮人であった」とまで 主張している ${ }^{17}$ 。灭山島』において日本に密航してきた康蒙九と南承之が日本共産党社 を訪問し党員である在日朝鮮人金祐在と面談するのも、こうした歴史的な文脈から理解 できる。では、済州島からの援助要請に対し、日本共産党はどう対応しているだろう か。

ただ日本共産党は日本帝国主義の壊滅という歴史的状況、つまり米軍占領下の現 実のなかで再建された労㗢者農民の前衛組織です。端的にいうならば、党が占領下 平和革命路線を堅持している日本の現実、政治的諸情勢と、南朝鮮における主、客観 的な政治情勢とは基本的な相違があるわけです ${ }^{18}$ 。

在日朝鮮人党員金祐在によれば、日本共産党は済州島における武装蜂起の正当性を認 めるものの、「党が占領下平和革命路線を堅持している」ということを理由に、武装闘争 への公式的な援助はできないという。こうした反応は日本共産党における一国中心主義 を云々する以前の問題として、日本と済州島において連合軍の占領の方式とそれに対応 する人々の態度がそれぞれ違っていたことに起因する。

済州島から来た密航者たちは占領下において日本共産党の存在や彼らの活動は全く合 法的であることに驚かずにはいられない。戦前非合法的な政治組織として政治的な弾圧 を余儀なくされた日本共産党は、GHQによる治安維持法撤廃と政治犯開放をきっかけに 合法政党として再建しようとした。1946年開かれた第五回党大会宣言で、「我が国のブ ルジョワ民主主義革命を、平和的に、かつ民主主義的方法によって完成することを当面 の基本目標とする」と宣言し、実際に一九四六年四月の選挙で五議席を獲得した ${ }^{19}$ 。それ に対し、アメリカ軍によって信託統治された朝鮮半島の南においては、朝鮮共産党や南 労党のような共産主義系列の政党はあったものの、共産化をきらうアメリカ軍政の工作 による弾圧と、アメリカ軍政を全面的に拒もうとする指導部の判断によって朝鮮共産党 や南労党が合法政党化できなかったのだ。むろん、日本共産党に対するGHQの政治的な 弾圧が全くなかったわけではないものの、国土分断を回避し、主にアメリカ軍によって 占領されていた日本列島において合法的な日本共産党の存在は、占領が戦前とは違う政 治的な「自由」をもたらした証拠としても機能したはずである。

『火山島』において少なくともそうした政治的な自由が許されていないと判断し武装 蜂起の準備のため済州島から密航してきた人々の目には、血を流す内戦を回避する合法

16 尹健次『在日の精神史 I』(岩波書店, 2015), p.121.

17 尹健次『在日の精神史 I』(岩波書店, 2015), p.121.

18 金石範『火山島 II』(岩波書店, 2015), p.150。

19 福富健一『日本共産堂の正体』(新潮社, 2019), pp.81-89. 
的な共産党という道もあるということが 大きな「違い」として見えてきた。そしてその 違い、つまり一九四五年から一九四八年までのあいだに、東アジアにおける同じ持ち主 による、異なる占領の統治方式が働いていたという事実こそが、人を移動させる原理と なっていたのではなかろうか。もし日本においても合法的な共産党活動が拒まれ、パル チザンによる武装闘争が企てられていたらば、朝鮮半島に対する一切の援助の期待さえ できなかったはずだっただろう。

このように『火山島』における日本への「密航」は、同じく占領の下にあるものの、そ の統治方式の違いを浮き彫りにするための物語的な装置として機能している。さらにそ れは、密航者の目に映った「占領」と、日本の戦後文学や歴史が伝える「占領」との違いも 生み出す。

今日、占領期日本は、アメリカ軍の空襲による壊滅的な破壊と連合軍の懲罰的な経済 政策のせいで、物資不足に悩まされる空間として描かれているのが一般的である。例え ば、ジョン・ダワーの『敗北を抱きしめて』に出てくる1947年神戸の三宮駅前で寝泊まり している人々の写真はその代表的な例であろう ${ }^{20}$ 。それに対し、『山島』における密航 者南承之の目に写った神戸は、次の通りである。

海と山に挟まれた帯状の、電車が横にひたすら走りつづける街。海の輝きと山の 緑の豊かさが一望のもとに入る美しい街だった。海と山の色を反射するように明る い萌黄のモダンな市電も街に似合っていた。どんよりした小豆色の大阪の市電より ずっといいんだと誇らしげに思ったたわいない時期もある。敗戦の年の三月の大空 襲に大半が焼けた街だったが、さっき神戸駅のホームからながめた港の明かり、繁 華街の明るさを見ても、すでに灰燼から立ち上り新しい息吹きをしていた。左右に 分かれて後方へ走り去る見覚えのあるビルなどの立ち並ぶ街のただずまいが、そこ に白昼の光を蘇らせてはっきり見えてくる ${ }^{21}$ 。

上記の部分は、植民地時代、君が代丸に乗って帝国日本にやってきて大学まで進学し たものの、戦時「非国民呼ばわり」をされた経験と解放された祖国に対する希望で敗戦直 後済州に帰ってパルチザンになった南の目に映った神戸だが、「灭燼から立ち上り新し い息吹き」をしている、「明るい」空間として表象されているのが特徵である。では、こ うした占領日本のイメージをどう理解すべきなのか。

それは、後に神戸市内で浮浪者の姿を見て南自ら反省しているように、「厳しい朝鮮 での生活に慣れた眼が、日本の現実に対する印象を美化し、飛躍させてしまっていた」 のにすぎないかもしれない。当時済州島の経済的な状況は厳しかったけれど、日本にお いても壊滅的な空襲で家や家族を失って飢えていた人々が大いにいた。とすると、済州 からの密航者の眼に写った占領期日本のイメージはあまりにも誇張的であると言わざる

20 ジョン・ダワー・三浦陽一・高杉忠明訳『敗北を抱きしめて』(岩波書店, 2004), p.109.

21 金石範『火山島 II』(岩波書店, 2015), pp.53-54. 
を得ない。

それにしても、『火山島』における占領期日本のイメージを完全たる虚構として相対 化することはできない。実はこうした占領期日本表象は、不法的に滞在している故に活 動範囲が限られている密航者の動線が極めて制限的であることと深くかかわる。つま り、彼らが日本で接触した人々のほとんどは在日朝鮮人であり、彼らは「朝鮮で食べら れん朝鮮の食べ物が、日本のここで食べられる」という表現から見るように、この密航 者たちを大いに歓待していた。こうした歓待の経験こそが、占領期日本に対する印象に 影響を与えていたのである。それでは、何が占領期日本に滞在している朝鮮の人々にそ れを可能にしたのだろうか。

『火山島』における占領期の在日朝鮮人は、貧しい状況に追い込まれているよりは、 新しい希望で生き生きしているように印象づけられている。例えば南承之の親戚である 南承日は、神戸の新湊川辺りに位置する運動鞉の甲皮工場を拡大しゴム長靴まで造るゴ 厶工場を経営しているし、「ふるさとの人間が多く住んでい」る大阪の猪飼野へ引っ越し た南承之の母は、「朝鮮服の需要に格段の差があって、仕事に暇になることがなっいほど である。尹健次が指摘しているように敗戦直後の日本では配給制度は破綻し、米や衣 服、ゴム製品のような生活用品が極めて不足していたけれども、猪飼野の朝鮮市場のよ うな闇市ではこうしたものの取引が活発に行われていた ${ }^{22}$ 。二人のように在日朝鮮人の 多くは闇市で統制物資を売ることで生活を維持したのである。在日朝鮮人にとって占領 期日本の「自由と民主主義」とは、まさにアメリカ軍の厳しい統制が届かなかった闇市に おいてのみ見出されていたけれども、こうした印象がやがて朝鮮半島から日本への密航 を決意させる大きな理由の一つとなっていく。

『火山島』に抢ける占領期日本に対する肯定的な視線は、まだ日本政府による出入国管 理体制が完備されていなかったことともかかわる。1947年占領軍によって外国人登録令 が施行されていたものの、不法入国者を厳しく取り締まり大村入国者受容所に送り込む ような措置はまだなかったのである。それに、朝鮮半島の分断に伴う在日朝鮮人同士の 分裂もまだ始まっていない。このことも祖国統一を目指す武装闘争準備のために日本に やってきた密航者の眼に、占領日本が明るく表象されている理由である。

『火山島』に㧍ける密航者の視線に見る占領日本は、やがて安定される戦後日本のそれ と異なるしかない。後者の場合、まだ完備されていない法秩序の空間として占領期は、 のり越えるべき対象だった。アメリカ軍による占領期を、無秩序の空間として記憶する ことによって、ポスト占領期をより安全で自由な空間として維持することができたので ある。実際に密航と闇市とかかわっていた在日朝鮮人は、占領が終わるにつれて、どん どん犯罪人のように扱われることとなったことは周知の通りである。このことは密航 を語ることを難しくした理由でもあった。

22 尹健次『在日の精神史 I』(岩波書店, 2015), p.102. 


\section{$44 \cdot 3$ 以降の「密航」一済州島における二つの「法」からの逃れ道}

『火山島』において渡航を通じた移動の制限は国家と国家とのあいだに限られない。

1948年4月3日に済州島で武装蜂起が起こると、4月5日に済州非常警備司令部が設置さ れて討伐に備えると同時に、道令を公布し他の地域との海上交通を一切遮断し、アメリ 力艦艇で海岸を封鎖した。同年5月10日に行われた選挙に、済州の人々が非協力的であ ると判断し、武装隊の活動が収まる気配が見られないと、アメリカは駆逐艦クレイグ号 を済州に送り、海岸を一層厳しく封鎖していく。この封鎖によって、事件そのものに関 する報道を遮断した上で、あたかも南だけで行われた選挙が無事に行われたかの印象を 与えようとしたのである。こうして大韓民国政府が樹立した8月からは一度廃止した旅 行証明制度が復活し、移動の制限を保ったうえで本土からの応援警官隊を増員され、武 装隊に対する大規模の討伐戦を展開する。11月に入ってからは武装隊だけではなく、住 民の虐殺も激しくなるにつれて、11月17日に李承晚大統領が済州道全域に戒厳令を敷く と、本格的な「焦土化」が行われることとなる。国家は、自らの意見を逆らう一部の地域 に住む人々の移動を制限することによって、大韓民国という新しい「大地」の法を樹立し たのである。

ただしここで注意すべきなのは、移動の制限はすべての済州の人々に平等に適用さ れなかったということである。

『火山島』においてブルジョワ階級の長男である李芳根は、比較的に自由に済州島とソ ウルを往来している。例えば4月10日夜に警官梁俊午という親類の協力で旅行証明書も ないまま木浦行きの連絡船に乗り、後から郵便で旅行証明書をもらい、18日に済州に 帰ってくるほどであるし、それは彼の妹李有媛にも同じく当てはまる。彼女は4月3日の 夜に済州を離れるが、李芳根がソウルを離れた 3 日後に不意に済州に帰ってくる。移動 方法を伺う兄に対し、彼女は「中央軍政庁の局長をしている」父親をもつ友人に頼んで、 「その扮さんから首都警察庁へ紹介してもら」い、「父急病のため帰鄉ということで旅 行証明書」をもらったという 23 。このような李芳根兄妹の「自由」な移動は、政治的な信 念や階級的な違いによって移動がどのような形を取るのかを前景化する機能を果たす。 例えば次の場面は済州の人々にとって密航」が階級とかかわっていたことを端的に示し てくれる。

「李先生ニム、あの、密航というのは扔かしいですか?」

吳南柱が思い出したようにいった。

「いや、おかしくない。密船がおかしくないようにだ。一昨日、ソウルへ来たと いう姻戚の方も密船でだろう。つまり、それが密航なんだな。……う一ふん、た だ、私は、この密航でなかっただけなんだ。きみたちの気に入らんだろうが、“特 権階級,だよ」 24

23 金石範『火山島 III』(岩波書店, 2015), p.477. 
済州出身の大学生であり家族の安否が気になっていた遣南柱は、李有媛に対し「是非

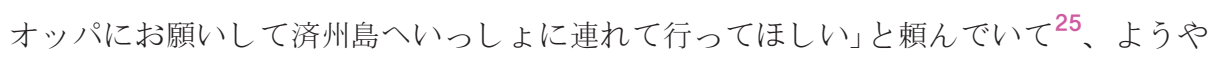
く李芳根との相談の機会を得るが、そのあいだに状態が変わり、「密航でもして秘密に 上陸するならば別だけど、先生二ムといっしょに行く場合は、いまのぼくはすでに身 元が分かってしまっている」から行かないという。故郷に帰ることが身を晒す危険な行 為であるがゆえに密航でなければ自分の故郷に帰られないという、彼の主張の前に、李 芳根は自分が「特権階級」にすぎないということを改めて認識せざるを得なくなる。

このことは、密航をめぐって済州島の人々における存在の格差を浮き彫りにする。 密航とは、法に保護されないがゆえに法の外でしか生の可能性を見いだせない人々の存 在の痕跡でもある。ここに移動制限という権力の恐ろしさが改めて確かめられる。すな わち「主権者とは非常事態についての決断者である」というシュミットの言葉に倣い言う ならば ${ }^{26}$ 、李承晚は戒厳令を決断することによって人々を大地二法の枠に閉じ込み、本 来人々の方にあるはずの主権を奪っていたと言えなくもないのだ。

『火山島』においてその権力は、警備団、西北青年団、資産家、資産家の長男といった 順に分配され、彼らを通してそのほかのすべての済州島の人々に対し行使されるが、こ うした権力のヒエラルキーの最下位におかれた済州の女性は、こうした大地＝法に翻弄 されるしかない。それはいくら李有媛のようなブルジョワ階級のような人にも例外で はないと『火山島』では語られている。

ソウルの音楽大学生である李有媛は、1948年8月15日大韓民国政府樹立に反対するデ モに参加して警察に検挙されるほど強い政治的な信念の持ち主であり、パルチザンの南 承之とも恋愛関係ももつ。こうした彼女を心配する彼女の兄芳根は、彼女を日本へ留学 をさせようと働きかけるが、彼女の将来を決定する権利は、あくまでも彼女の父李泰洙 に帰属している。親権者である父は、自分の日本行きを説得しに済州に帰ってきた彼女 に対し、逆に渡航証明書を発行させないよう働きかけることによって彼女を済州島に留 まらせ、事実上拘束するのである。こうして李有媛の姿は、済州島を支配するもう一つ の陸の法を浮き彫りにさせる。

それは李泰洙に代表される家父長制という法である。女性を単なる性的な対象か、家 父長制の再生産の道具としかみない李泰洙の存在は、済州島を支配する新しい法以上 に、彼の息子李芳根と李有媛の生を強く縛り付けている。政治的な理念こそ衝突するも のの、経済的には父に寄生する娘李芳根にとってその呪縛から解き放つための唯一の手 段は、日本への密航船に乗ることでしかなかったし、だからこそ李有媛を日本へ密航さ せることを決心し、成功させることとなる。ブルジョワ階級の彼女でさえ日本に密航せ ざるをえなくなる状況が、まさしく『火山島』において当時済州島の「現実」にほかならな

24 金石範『火山島 $\mathrm{V}_{\Perp}$ (岩波書店, 2015), p.469.

25 金石範『火山島 $\mathbb{V}_{』}($ 岩波書店, 2015), p.210.

26 カール・シュミット・長尾龍一(編)『カール・シュミット著作集 I』(慈学社出版, 2007), p.2. 
かったのである。

『火山島』において4・3後に行われる日本への「密航は、まさしく自分こそが主権者で あるということを宣言するかのように敷かれた戒厳令によって明瞭にあらわれた新し い法権力と、済州島にしつこく根付いていた家父長制という古い権力から逃れる道で あった。いずれも大地の法からの逃走であるがゆえに、大地の法の観点からみれば密航 は常に不法にしか見えないかもしれない。だが、観点を変えれば、それは不法よりは 超法的な行為であると言えなくもない。

実際に『火山島』では、国法の外へ赴く密航船で、かつて「親日派」であり現に武装隊と 政府側との二重スパイである人物柳達絃が、武装隊の若者たちによって処罰されるとい う場面がある。法が届かないところで行われるこの処罰は、単に一人の悪質な裏切り者 に対する審判ではなく、彼が常に背負っていた大地の法に対する審判でもある。むろ ん、それは海の上でしかできないがゆえに、限りなく虚構に違いないが、それこそ『火 山島』を通して金石範が示そうとした「越境」の在り方ではなかろうか。

\section{5 まとめ: 密航を書くということの勇気と可能性}

これまで見てきたように、『火山島』における「密航」は、戦後東アジアにおける「陸」 の法の在り方をもっとも鮮明に浮き彫りにする物語的な装置として働く。その「法」は、 戦後朝鮮半島を分断する二つの勢力から、圧倒的な軍事力で君臨しはじめるアメリカ軍 政の法令、それに依存し成立した韓国政府の法律のみならず、主人公李芳根の家に代表 される家父長制をも含む。とりわけ、4・3以前に行われる日本への「密航は、同じくア メリカによって占領されるものの、韓国と日本との法の働き方式の違いをも浮き彫りに し、事件後日本への密航を説明してくれる根拠となるという面においても重要である。

密航は法の外に赴くという面において違法であるが、そうしないといけないほど追 い込まれた極限の生の痕跡をも見せてくれる。法の正当性に疑問を投げかけ抵抗したと いう理由で、法の保護を受けなくなった済州の人々にとって、この封鎖の上で行われた 焦土化から逃れるための唯一の道が密航であった。だからこそ、密航者として日本にた どり着いた在日朝鮮人は、大韓民国といら国家の根源において流された血の痕跡を、存 在それ自体で証言する。

そして密航はいうまでもないが、その密航を語るということも極めて危なく、大き な勇気の要る行為であることも忘れてはならない。密航の証言としての『火山島』を書く ことで金石範は2015年「済州4・3平和賞」を受賞するものの、同じ年に韓国政府によって入 国拒否された。正確な理由は明かされなかったものの、当時の政府にとっては李承晚政 権に対する批判は、大韓民国の正当性に対する批判に映っていたと推測されている ${ }^{27}$ 。

27 「韓国、金石範氏の入国拒否 過去の政権を批判、影響か」(『朝日新聞』, 2015.10.16). 
確かに『火山島』は、大韓民国成立における暴力を真正面から語っているし、密航はそれ を浮き彫りにするもっとも有効的な装置として欠かせないものであった。

密航を語るということの危なさは、韓国のみならず、日本においても当てはまる。 桜井誠のような排外主義者たちは、「密航」を根拠に現にいる在日朝鮮人を違法者として 表象しようとしていたということは周知の通りである。そうした危険性があるにもか かわらず、あえて在日朝鮮人の密航を語った理由はどこにあったのか。

それは、密航がいわば「過去起こった事実」として歴史に記載されることで収まらな い、何らかの可能性に開かれているからではなかろうか。すなわち、大地の法に縛ら れている歴史の外に赴け、陸と海を跨るという、普段なかなかできない経験に導くため にこそ、金石範にとって密航を書くということの意義があったのではなからうか。

\section{参考文献(Bibliography)}

朝日新聞社 (2015)「韓国、金石範氏の入国拒否・過去の政権を批判、影響加『朝日新聞』2015.10.16. Asahishibunsha(2015) Kankoku, kim Sok-bum no nyukokukyohi kako no Seiken wo hihan, eikyoka, Ashishibun.2015.10.16.https://mww.asahi.com/articles/DA3S12019471.html

カール・シュミット、新田邦夫(訳) (1995)『パルチザンの理論』, 東京 : 筑摩書房. Carl, Schmitt, translated by Nitta Kunio (1995) Parutizan no riron. Tokyo : chikumashobou.

カール・シュミット, 新田邦夫 (訳) (2007)『大地のノモスーヨーロッパ公法という国際法における』, 東京 : 慈

学社. Carl. Schmitt. translated by Nitta Kunio(2007) Daichi no nomos : Europa kohou toiu kokusaiho niokeru. Tokyo : Jigakusha.

カール・シュミット, 長尾龍一(編) (2007)『カール·シュミット著作集 I』, 東京 : 慈学社. Carl, Schmitt, edited by Nagao ryuichi(1995) Carl Schmitt tyosakusyuu. Tokyo : Jigakusha.

金石範(2015)『火山島 I 』. 東京：岩波書店. Kim Sok-bum(2015) Kazando /, Tokyo：Iwanamishoten. 金石範 (2015)『火山島 II』. 東京：岩波書店. Kim Sok-bum(2015) Kazando /I, Tokyo：Iwanamishoten. 金石範(2015)『火山島III』, 東京：岩波書店. Kim Sok-bum(2015) KazandoIII, Tokyo：Iwanamishoten. 金石範(2015)『火山島IV』。東京：岩波書店. Kim Sok-bum(2015) Kazando $N$, Tokyo：I wanamishoten. 金石範(2015)『火山島IV』. 東京：岩波書店. Kim Sok-bum(2015) Kazando $N$. Tokyo：I wanamishoten. ジョン・ダワー、三浦陽一・高杉忠明(訳) (2004)『敗北を抱きしめて』. 東京：岩波書店. John Dower, translated by Miura youichi \& takasugi tadaaki (2004) Haiboku wo dakisimete, Tokyo : Iwanamishoten.

福冨健一(2019)『日本共産堂の正体』, 東京：新潮社. Hukutomi Kenichi(2019) Nihonkyousando no Shoutai, Tokyo : Shinchousha.

文京洙 (2018)『済州島四·三事件——「島の国」の死と再生の物語』.東京：岩波書店. Mun GyongSu(2018)

Jeju-do 43ziken : 'shima no kuni' no shi to saisei no monogatari. Tokyo : Iwanamishoten.

尹健次 (2015)『在日の精神史 I 』, 東京 : 岩波書店. Yun koncha(2015) Zainich no seishinshi I I wanamishoten.

고명철 (2016)「해방공간의 혼돈과 섬의 혁명에 대한 김석범의 문학적 고투」. 濟州: 『영주어문』34. pp.183-217. Ko Myeoung-Cheol(2016) Haebanggongganui Hondonkwa Seomui Hyoukmyonge daehan Kim sok-bumui Munhakjuk Gotu. Yongjuomun Vol.35. pp.183-217

https://www.asahi.com/articles/DA3\$12019471.html 
곽형덕 (2017) ‘망명자문학’으로서의『화산도』, 술山 : 『한민족문화연구』57, pp.37-62. Kwak Hyoung-Duck (2017) 'Mangmyoungjamunhak' uirosoui Hasando, Hanminjokmunhwayoengu. Vol.57. pp.37-62.

권성우(2016)『비평의 고독』, 서울 : 소명출판. Kwon Seongwoo(2016) Bipyeongui godok. Seoul: Somyongchulpan.

권혁태, 이정은. 조경희(편) (2017)『주권의 야만』, 경기도 : 한울엠플러스. Kwon Heoktae, Lee Jungeun, Cho Kyunghee (2017) Jukwonui Yaman. Kyongido: Hanulemplus.

제주4 · 3 사건진상규명및희생자명예회복위원회 (2003)『제주43사건 진상보고서』, 서울 : 선인. Jeju43sakwonjinsanggyumyengmit huisangja myungyehouibokwiwonhoui (2003) Jeju 43sakwon Jinsangbogoseo, Seoul : Seonin.

정영환, 임경화(역) (2019)『해방공간의 재일조선인사』. 서울 : 푸른역사. Jeong yonghwan, translated by Lim Kyonghwa(2019) Haebanggonganui Jaeilchosuninsa, Seoul : puruneoksa.

조경희 (2015)「불완전한 영토, '밀항'하는 일상」, 서울 : 『사회와역사』106권, pp.39-75. Cho Kyunghee(2015) Bulwanjwonhan Yongto, 'Milhang'hanun ilsang. Seoul : Sahuiwa Eoksa Vol.106. pp.39-75. 